\title{
sciendo
}

\section{THE EFFECT OF LIGHT/DARK CYCLES ON PERFORMANCE AND WELFARE IN BROILER}

\author{
Murat Ozkan, Ulku Gulcihan Simsek* \\ Department of Animal Science, Faculty of Veterinary Medicine, Firat University, 23119 Elazig, Turkey \\ •Corresponding author: gsimsek@firat.edu.tr; gsimsek44@gmail.com \\ Ulku Gulcihan Simsek ID: https://orcid.org/0000-0003-2871-3005 \\ Murat Ozkan ID: https://orcid.org/0000-0002-4228-8052
}

\begin{abstract}
The purpose of this study was to compare a continuous lighting programme (23 hours of lighting (L)/1 hour of darkness (D)) with intermittent lighting programmes (16L: 8D) and also to investigate the effects of the length of the dark cycle in the intermittent programme on the performance, carcass characteristics, water consumption, uniformity, metabolic parameters, and ammonia burns of chickens. Thus, five hundred Ross 308 male chicks were used. The 23L:1D programme was applied to the chicks for 7 days. On day 7 , they were divided into four groups by balancing their live weight; group I: continuous 23L:1D; group II: intermittent 4x (4L:2D); group III: intermittent 2x (8L:4D); group IV: continuous 16L:8D. The study took place between days 7 and 42 . At the end of the study, 10 chickens from each group were slaughtered, their carcass, blood, and bone properties were analysed. Body temperatures and ammonia burns were assessed for all broiler chickens. The mean live weight of group IV was the lowest. The difference among the groups in terms of live weight gains, feed intakes, feed conversion ratios, and survival rates was non-significant. Long-term darkness in group IV significantly dropped the water consumption. On day 21, group III's best uniformity was calculated; but on day 42, the difference was non-significant. The highest breast ratio and the lowest wing ratio belonged to chicks in group $I_{\text {. Their free }} \mathbf{T}_{4}$, glucose, and uric acid levels were lower; whilst their testosterone levels were higher. Body temperature and tibia ash levels were similar across all of the groups. The intermittent lighting programmes increased the number of ammonia burns. Consequently, the long-term darkness negatively affected both the chickens' performance and well-being.
\end{abstract}

Key words: broiler, lighting programme, production, hormone, ammonia burns

Duration of lighting can have important effects on some parameters of broiler chickens such as feeding activity, water drinking, scratching, resting, muscle and bone development, hormone secretion, enzyme system, and stimulation of the immune system (Olanrewaju et al., 2019; Soliman and El-Sabrout, 2020). The length of the light/dark cycle is involved in significant metabolic events and controlling the activities such as control of body temperature, rhythmic and synchronised functions of the body, growing, maturing, and reproduction (Soliman and Hassan, 2019; Pandey, 2019; Baykalir et al., 2020).

Non-intermittent and intermittent lighting programmes are applied in broiler houses. Non-intermittent lighting is the type of (close to) 24-hour lighting programme. It serves to maximise the broilers' growth rate by activating their feed consumption (Soliman and Hassan, 2019). Genetic improvement alongside various care and feeding strategies used in broiler breeding increase growth rate, thus improving productivity of businesses whilst lowering production costs. However, a higher growth rate can increase physiological stress of broilers and cause them to suffer from leg problems, cardiovascular disorders, excessive fat deposition, heightened sus- ceptibility to environmental conditions and diseases, and reduced vitality (Olanrewaju et al., 2018). Recent studies (Hassanzadeh et al., 2012; Manfio et al., 2019) have indicated that short-day length (intermittent lighting) saves energy and has a positive effect on broiler's welfare. Other studies (Jia et al., 2016; Calislar et al., 2018) have revealed that melatonin activates poultry's growth hormone, and improves their feed conversion. This hormone increases their live weight gain by regulating their heat mechanisms, energy metabolism, sexual maturity, and reproductive functions. It also protects them against heat stress, boosts their immune system, and has significant functions in the yields related to bone metabolism (Pandey, 2019). Melatonin is secreted by the epiphysis during the dark cycle and in the retina during the light cycle; in fact, $80 \%$ of melatonin into the blood circulation is secreted by the epiphysis. Moreover, the skin, testicles, bone marrow, blood platelets, lymphocytes, and gastrointestinal system secrete it at relatively low levels. A prolonged dark period increases melatonin level of poultry (Calislar et al., 2018).

Authorities have outlined (in directive 2007/43/EC) that in applications aiming to improve the welfare of broilers, a lighting of 20 lux should be placed at eye level 
of broiler chickens. The directive also states that lighting should be carried out in a 24-hour cycle during which broilers get to rest in the dark for minimum 6 hours (nonintermittent darkness of 4 hours) from 7 days after they arrive at the broiler house until 3 days before they get slaughtered (Bozkurt, 2017). Some studies (Yang et al., 2015; Olanrewaju et al., 2018) have shown that under different intermittent lighting programmes the chickens' welfare improves, their mortality rate drops, and their live weight increases. However, the length and mode (non-intermittent, intermittent, duration of intermittence) of the dark period are significantly effective on broilers' welfare and performance (Soliman and Hassan, 2019; Baykalir et al., 2020).

The aim of this study is to determine how intermittent (16L:8D) and non-intermittent (23L:1D) lighting programmes affect the performance and some blood and welfare parameters of broilers and how the period of light/ dark cycle $((2 \times(8 \mathrm{~L}: 4 \mathrm{D})$ and $(4 \times(4 \mathrm{~L}: 2 \mathrm{D})))$ in the intermittent lighting programme influences the related parameters.

\section{Material and methods}

\section{Animal care}

This study was conducted at the Agriculture \& Livestock Application Centre at Frat University. Firat University's Animals Experiments Local Ethics Committee (FÜHADYEK) (protocol no: 2017/43) had granted the approval to conduct the study.

\section{Experimental design}

The experimental units included five-hundred Ross 308 male broiler chicks (one-day old) that were supplied by a local private company. They were housed in four $12 \mathrm{~m}^{2}$ rooms with the same features that were lined to prevent light from penetrating through their walls. Each room was divided into five $2 \mathrm{~m}^{2}$ sections and lightened using 3 lamps (featuring 7-watt white light-bulbs), set up to be 1.75 watt $/ \mathrm{m}^{2}$. Digital clocks (CATA: CT-9180, 220-240V AC, 16L, 50Hz, 3500W, IP20) were placed into each room, and were pre-set to implement the required light/dark programme. To energise the clocks during power cuts, an uninterruptible power supply (UPS, Tuncmatic Economy 600VA) was installed onto them and the lighting system was supported. Each division was equipped with one 5-litre drinking bowl and a 3-kg feeder during the first ten days (later replaced with a $10-\mathrm{kg}$ feeder for the subsequent period). The rooms were heated using thermostat control electric heaters. The temperature and humidity of the rooms were arranged in accordance with the birds' needs. The doors of the rooms (which were open to the dark ventilated corridor) were air conditioned. Each room had a $5-\mathrm{cm}$ thick straw litter. Feed was prepared beforehand at a feed plant of a private company in accordance with National Research Council's standards. The broilers were fed according to a three-phase feeding programme, as shown in
Table 1. During week 1, the lighting was administered for 23 hours per day with a 1 -hour darkness period. At the end of week 1, all the chicks were weighed. After the chicks' initial live weights were brought up to a similar point, they were then assigned at random into several experimental groups; whereupon each group's clocks were preset and the scheduled lighting was initiated. Group I: the broilers were assigned to a programme of 23-hour light (L)/1-hour dark (D) (23L:1D). Group II: the broilers were assigned to a programme of 4L:2D:4L:2D:4L:2D:4L:2D (4x(4L:2D)). Group III: the broilers were assigned to a programme of $8 \mathrm{~L}: 4 \mathrm{D}: 8 \mathrm{~L}: 4 \mathrm{D}(2 \mathrm{x}(8 \mathrm{~L}: 4 \mathrm{D}))$. Group IV: the broilers were assigned to a non-intermittent dark programme of 16L:8D. Each group was arranged into five repetitions consisting of 25 broilers. The study took place for 7-42 days.

Table 1. Composition and nutritional properties of feeds

\begin{tabular}{|c|c|c|c|}
\hline Feed raw materials & $\begin{array}{l}\text { Days } \\
1-10 \\
\end{array}$ & $\begin{array}{c}\text { Days } \\
11-30\end{array}$ & $\begin{array}{c}\text { Days from } \\
31 \text { to slaughter }\end{array}$ \\
\hline Corn & 54.10 & 45.70 & 54.50 \\
\hline Wheat & - & 11.10 & 6.50 \\
\hline Vegetable oil & 1.30 & 3.50 & 4.00 \\
\hline Soybean meal ( $48 \%$ HP) & 30.10 & 25.10 & 24.50 \\
\hline Full fat soy & 8.00 & 8.20 & 6.17 \\
\hline Meat bone meal & 3.00 & 3.27 & - \\
\hline Dicalcium phosphate & 1.30 & 1.20 & 2.00 \\
\hline Limestone & 0.50 & 0.30 & 0.70 \\
\hline Sodium bicarbonate & 0.50 & 0.50 & 0.50 \\
\hline Salt & 0.30 & 0.30 & 0.30 \\
\hline DL-methionine & 0.40 & 0.40 & 0.40 \\
\hline L-Lysine & 0.10 & 0.05 & 0.05 \\
\hline Threonine & 0.10 & 0.08 & 0.08 \\
\hline Vitamin mix* & 0.20 & 0.20 & 0.20 \\
\hline Mineral mix $* *$ & 0.10 & 0.10 & 0.10 \\
\hline \multicolumn{4}{|l|}{ Nutrients } \\
\hline dry matter & 90.60 & 90.10 & 90.89 \\
\hline crude protein & 23.40 & 22.00 & 19.70 \\
\hline crude fiber & 3.20 & 3.50 & 3.58 \\
\hline raw oil & 5.83 & 7.75 & 8.34 \\
\hline ash & 5.50 & 5.30 & 3.91 \\
\hline calcium $* * *$ & 1.00 & 0.93 & 0.85 \\
\hline phosphorus usable*** & 0.51 & 0.51 & 0.44 \\
\hline methionine $* * *$ & 0.69 & 0.66 & 0.59 \\
\hline lysine $* * *$ & 1.44 & 1.27 & 1.11 \\
\hline threonine $* * *$ & 0.97 & 0.88 & 0.81 \\
\hline $\mathrm{ME}, \mathrm{Kcal} / \mathrm{kg}^{* * *}$ & 3.011 & 3.176 & 3.225 \\
\hline
\end{tabular}

*Vitamin mix: In each $2.5 \mathrm{~kg}$ mixture; vitamin A $12.000 .000 \mathrm{IU}$; vitamin $D_{3} 2.000 .000 \mathrm{IU}$; vitamin E $35.000 \mathrm{mg}$; vitamin $\mathrm{K}_{3} 4.000 \mathrm{mg}$; vitamin $\mathrm{B}_{1} 3.000 \mathrm{mg}$; vitamin $\mathrm{B}_{2} 7.000 \mathrm{mg}$; niacin $20.000 \mathrm{mg}$; calcium D-pantothenate $10.000 \mathrm{mg}$; vitamin $\mathrm{B}_{6} 5.000 \mathrm{mg}$; vitamin $\mathrm{B}_{12} 15 \mathrm{mg}$; folic acid 1.000 mg; D-biotin $45 \mathrm{mg}$; vitamin C $50.000 \mathrm{mg}$; choline chloride $125.000 \mathrm{mg}$; cantaxanthin $2.500 \mathrm{mg}$; apo-carotenoic acid ester contains $500 \mathrm{mg}$.

**Mineral mixture: In each one $\mathrm{kg}$ mixture; manganese $80.000 \mathrm{mg}$; iron $60.000 \mathrm{mg}$; zinc $60.000 \mathrm{mg}$; copper $5.000 \mathrm{mg}$; cobalt $200 \mathrm{mg}$; iodine $1.000 \mathrm{mg}$; There is $150 \mathrm{mg}$ of selenium.

***It was determined by calculation. 


\section{Sampling and examinations}

The broilers were weighed (in grams) once a week on a sensitive digital scale. Their live weight gains were calculated. The feed was weighed and given to them daily, whilst the remaining feed was weighed weekly. Their feed consumption was calculated based on the number of broilers that survived in each group. The subjects were given a constant supply of fresh feed. Their daily feed consumption rates were proportioned to how much daily live weight they gained and their feed conversion values were calculated accordingly. Water was always supplied ad libitum and it was first portioned out and recorded. The remaining water was also portioned out. As the drinking bowls were washed daily, how much water they consumed daily was measured on a digital scale. Uniformity was calculated by obtaining the percentage of the broilers within $\pm 10 \%$ of average live weight on days 21 and 42. To calculate their vitality (in terms of percent), these subjects which were alive on the days 21 and 42 were proportioned to the initial number of broilers (Simsek and Ozhan, 2015). Their body temperature was measured on day 42 by thermometer (Braun PRT 2000, EU), which had precisely measured all the broilers' cloacas up to $43^{\circ} \mathrm{C}$. All of the subjects' knee and footpad lesions in each repetition were scored on day 42 according to Skrbic et al. (2015). They were not given any food for eight hours before the slaughtering act.

At the end, all of the broilers were weighed. Two broilers having a live weight close to the average live weight of each repetition (i.e. 10 broilers from each group) were handpicked and slaughtered. They were made to fast for eight hours before the slaughtering act. They were slaughtered by using the neck-cutting method, and their blood was left to draw. Following the slaughtering act, their viscera were removed and their hearts, livers, and spleens were weighed. Each carcass was first weighed and then dissected following the Turkish Standards Institute's rules (TSI, 2014). When it came to carcass characteristics, carcass and visceral weights were in proportion to slaughter weight and expressed in percentages. All carcass parts were proportioned to carcass weight and expressed in terms of percent. The blood samples were brought to the laboratory in a cold chain centrifuged at $4000 \mathrm{rpm}$ for 4 minutes and their serum was detached. The sera samples were kept at $+4^{\circ} \mathrm{C}$ and taken to Firat University's Research Hospital Central Laboratory. Biochemical and hormone analyses were performed on the following day. Within the bone-ash analysis, the meat on the left tibiotarsal bones was removed with a bisturi. The bones were kept at $-20^{\circ} \mathrm{C}$ until analysis. Crude ash analysis was conducted on the bones thawed at $+4^{\circ} \mathrm{C}$. They were burned in a muffle furnace (Protherm, Turkey) at $600^{\circ} \mathrm{C}$ for 6-8 hours (Simsek and Ozhan, 2015).

\section{Statistical analysis}

While the live weights were determined individually for each broiler, the other parameters were determined individually for each repetition. The normality of the distribution of the data was tested using the Shapiro-Wilk test. One-way analysis of variance (ANOVA) was used to compare the groups with one another. Further comparisons were done with the Tukey HSD test and Levene's (homogeneity) test. SPSS 21 was used to perform all of the analyses. The features were expressed as mean \pm standard error. If it was $\mathrm{P} \leq 0.05$, the differences were accepted as significant.

Table 2. The effect of different light/dark cycles on some performance parameters in broiler chickens: Live weight, live weight gain

\begin{tabular}{|c|c|c|c|c|c|}
\hline Days & $\begin{array}{l}\text { Group I } \\
\text { (23L:1D) }\end{array}$ & $\begin{array}{c}\text { Group II } \\
(4 \mathrm{x}(4 \mathrm{~L}: 2 \mathrm{D}))\end{array}$ & $\begin{array}{c}\text { Group III } \\
(2 \times(8 L: 4 D))\end{array}$ & $\begin{array}{l}\text { Group IV } \\
(16 \mathrm{~L}: 8 \mathrm{D})\end{array}$ & $\mathrm{P}$ \\
\hline \multicolumn{6}{|c|}{ Live weight (g/chicken) } \\
\hline 7 & $196.40 \pm 3.66$ & $196.57 \pm 3.62$ & $196.25 \pm 3.69$ & $196.49 \pm 3.64$ & NS \\
\hline 14 & $548.95 \pm 28.26$ & $511.88 \pm 9.01$ & $526.69 \pm 8.22$ & $512.93 \pm 7.34$ & NS \\
\hline 21 & $992.16 \pm 17.52 \mathrm{a}$ & $980.94 \pm 16.16 \mathrm{a}$ & $988.36 \pm 12.06 \mathrm{a}$ & $920.75 \pm 10.95 \mathrm{~b}$ & $* *$ \\
\hline 28 & $1592.49 \pm 25.77 \mathrm{a}$ & $1565.46 \pm 17.55 \mathrm{a}$ & $1486.21 \pm 18.74 \mathrm{~b}$ & $1413.96 \pm 14.07 \mathrm{c}$ & $* * *$ \\
\hline 35 & $2323.77 \pm 52.05 \mathrm{a}$ & $2266.64 \pm 27.20 \mathrm{ab}$ & $2215.38 \pm 50.80 \mathrm{~b}$ & $2096.45 \pm 77.76 \mathrm{c}$ & $* * *$ \\
\hline 42 & $2883.76 \pm 64.68 \mathrm{a}$ & $2835.28 \pm 81.83 \mathrm{a}$ & $2801.81 \pm 79.92 \mathrm{a}$ & $2582.07 \pm 107.51 \mathrm{~b}$ & $* * *$ \\
\hline \multicolumn{6}{|c|}{ Live weight gain (g/chicken/day) } \\
\hline $7-14$ & $50.36 \pm 3.7$ & $45.04 \pm 1.31$ & $47.20 \pm 1.00$ & $45.20 \pm 1.05$ & NS \\
\hline $15-21$ & $63.31 \pm 1.97 \mathrm{a}$ & $67.00 \pm 1.08 \mathrm{a}$ & $65.95 \pm 0.55 \mathrm{a}$ & $58.25 \pm 0.56 \mathrm{~b}$ & $* * *$ \\
\hline $22-28$ & $85.76 \pm 1.61 \mathrm{a}$ & $83.50 \pm 1.18 \mathrm{a}$ & $71.12 \pm 2.19 \mathrm{~b}$ & $70.45 \pm 2.13 \mathrm{~b}$ & $* * *$ \\
\hline $29-35$ & $104.46 \pm 4.13$ & $100.16 \pm 3.49$ & $104.16 \pm 9.8$ & $97.49 \pm 9.82$ & NS \\
\hline $36-42$ & $79.99 \pm 4.10$ & $81.23 \pm 7.99$ & $83.77 \pm 14.08$ & $69.37 \pm 5.62$ & NS \\
\hline $7-42$ & $76.78 \pm 1.86$ & $75.39 \pm 2.4$ & $74.44 \pm 2.31$ & $68.15 \pm 2.97$ & NS \\
\hline
\end{tabular}

Data are given as mean \pm standard error. NS: Non-significant, $* * \mathrm{P}<0.01, * * * \mathrm{P}<0.001 . \mathrm{a}, \mathrm{b}, \mathrm{c}-$ the difference among the means expressed in different letters in the same line is significant. 


\section{Results}

Table 2 shows the effects of the L/D cycles on the live weights and live weight gains of the broilers. On day 7 , the live weights (at the beginning of the test) were equalised. The 14th-day live weights of the broilers included in the test were similar to each other $(\mathrm{P}>0.05)$. The highest live weights on days $21(\mathrm{P}<0.01), 28,35$, and $42(\mathrm{P}<0.001)$ were determined in group I, which was followed by groups II, III, and IV. At the end (day 42), the live weight of group IV was the lowest among all four groups $(\mathrm{P}<0.01)$ and groups I, II, and III, on the other hand, exhibited similar values. The live weight gain of group IV was found to be the lowest between days 15-21 and $22-28(\mathrm{P}<0.001)$ and the groups had similar values in the other periods. The live weight gains of the groups between days 7 and 42 were non-significant.

Table 3 shows the effect of different $\mathrm{L} / \mathrm{D}$ cycles on daily feed consumptions and feed conversions of the broilers. Between days 7 and 14, the highest feed consumption belonged to group I $(\mathrm{P}<0.05)$, followed by groups IV, III, and II. The highest feed consumption between the days 15-21 was observed in group I, while the lowest feed consumption belonged to group IV $(\mathrm{P}<0.05)$. The feed consumption between the days 22-28 was higher in groups III and IV compared to groups I and II $(\mathrm{P}<0.01)$. Each group's feed consumption values were not significantly different on days $29-35,36-42$, and 7-42. The feed conversion values between days 22-28 were higher in groups I and II compared to groups III and IV $(\mathrm{P}<0.001)$. In other periods, there was no statistical difference $(\mathrm{P}>0.05)$ among the groups in terms of feed conversion.

Table 4 shows the water consumption of the groups. Their water consumption decreased significantly be- tween days 7 and $14(\mathrm{P}<0.05), 15$ and $21(\mathrm{P}<0.05)$, and 22 and $28(\mathrm{P}<0.001)$, as the dark period was prolonged. There was no significant difference among the groups on days 29-35 and 36-42 in terms of water consumption $(\mathrm{P}>0.05)$. While the highest water consumption was determined in group I on days 7-42, the lowest value was determined in group IV $(\mathrm{P}<0.05)$.

Figure 1 shows the flock uniformity of the groups on days 21 and 42. Figure 2 shows their vitality rates. The uniformity rates of groups I, II, III, and IV on day 21 were $78.61,77.48,88.45$, and $74.28 \%(\mathrm{P}<0.05)$, respectively. On day 42 , they were $63.52,64.98,75.58$, and $60.93 \%$ respectively. Their vitality rates were 96.00, 97.60, 97.60 , and $98.40 \%$, on day 21 and $92.80,93.60,91.20$, and $95.20 \%$ on day 42 , respectively (in the same order). There was no significant difference between them.

Table 5 shows how the lighting programme affected certain carcass characteristics of the groups. Group I exhibited both the highest breast weight and the lowest wing weight $(\mathrm{P}<0.001)$. None of the groups showed significant differences in terms of the other characteristics.

Table 6 shows certain blood parameters of the groups. Group IV exhibited the highest free $\mathrm{T}_{4}$, glucose, and uric acid levels $(\mathrm{P}<0.05)$. Group I had the highest testosterone level $(\mathrm{P}<0.05)$. Free $\mathrm{T}_{3}$ level did not differ significantly among the groups.

Table 7 shows the effects of the L/D cycles on certain welfare characteristics. The groups showed similar body temperature and tibia ash levels $(\mathrm{P}>0.05)$. Analysis of the ammonia burns revealed that group I had lower right foot $(\mathrm{P}<0.001)$, right knee, left foot and left knee lesions $(\mathrm{P}<0.01)$, whereas groups II, III, and IV were significantly similar in terms of ammonia burns.

Table 3. The effect of different light/dark cycles on some performance parameters in broiler chickens: Feed intake and feed conversion rate

\begin{tabular}{|c|c|c|c|c|c|}
\hline Days & $\begin{array}{l}\text { Group I } \\
\text { (23L:1D) }\end{array}$ & $\begin{array}{c}\text { Group II } \\
(4 \mathrm{x}(4 \mathrm{~L}: 2 \mathrm{D}))\end{array}$ & $\begin{array}{c}\text { Group III } \\
(2 \times(8 \mathrm{~L}: 4 \mathrm{D}))\end{array}$ & $\begin{array}{l}\text { Group IV } \\
\text { (16L:8D) }\end{array}$ & $\mathrm{P}$ \\
\hline \multicolumn{6}{|c|}{ Feed intake (g/chicken/day) } \\
\hline $7-14$ & $103.41 \pm 4.72 \mathrm{a}$ & $83.39 \pm 5.28 \mathrm{~b}$ & $95.42 \pm 2.82 \mathrm{ab}$ & $98.12 \pm 2.51 \mathrm{ab}$ & $*$ \\
\hline $15-21$ & $103.96 \pm 5.70 \mathrm{a}$ & $82.95 \pm 4.87 \mathrm{~b}$ & $83.43 \pm 5.69 \mathrm{~b}$ & $77.03 \pm 8.31 \mathrm{c}$ & * \\
\hline $22-28$ & $108.09 \pm 2.82 \mathrm{~b}$ & $109.04 \pm 4.02 \mathrm{~b}$ & $127.04 \pm 4.00 \mathrm{a}$ & $126.79 \pm 1.99 \mathrm{a}$ & ** \\
\hline $29-35$ & $180.16 \pm 4.32$ & $173.62 \pm 3.18$ & $176.87 \pm 5.20$ & $166.61 \pm 7.29$ & NS \\
\hline $36-42$ & $176.72 \pm 10.23$ & $180.56 \pm 10.24$ & $193.92 \pm 9.92$ & $172.22 \pm 6.76$ & NS \\
\hline $7-42$ & $134.47 \pm 4.54$ & $125.91 \pm 3.59$ & $135.33 \pm 3.57$ & $128.15 \pm 3.82$ & NS \\
\hline \multicolumn{6}{|c|}{ Feed conversion rate ( $g$ feed intake/g live weight gain) } \\
\hline $7-14$ & $2.06 \pm 0.16$ & $1.86 \pm 0.15$ & $2.02 \pm 0.07$ & $2.17 \pm 0.06$ & NS \\
\hline $15-21$ & $1.63 \pm 0.11$ & $1.24 \pm 0.09$ & $1.26 \pm 0.08$ & $1.31 \pm 0.13$ & NS \\
\hline $22-28$ & $1.26 \pm 0.05 \mathrm{~b}$ & $1.30 \pm 0.05 \mathrm{~b}$ & $1.78 \pm 0.04 \mathrm{a}$ & $1.80 \pm 0.04 \mathrm{a}$ & $* * *$ \\
\hline $29-35$ & $1.73 \pm 0.05$ & $1.73 \pm 0.04$ & $1.69 \pm 0.21$ & $1.70 \pm 0.13$ & NS \\
\hline $36-42$ & $2.21 \pm 0.09$ & $2.22 \pm 0.16$ & $2.31 \pm 0.56$ & $2.48 \pm 0.11$ & NS \\
\hline $7-42$ & $1.76 \pm 0.04$ & $1.67 \pm 0.05$ & $1.82 \pm 0.08$ & $1.88 \pm 0.02$ & NS \\
\hline
\end{tabular}

Data are given as mean \pm standard error. NS: Non-significant, $* \mathrm{P}<0.05, * * \mathrm{P}<0.01, * * * \mathrm{P}<0.001$. a, $\mathrm{b}, \mathrm{c}-$ the difference among the means expressed in different letters in the same line is significant. 
Table 4. The effect of different light/dark cycles on water consumption in broiler chickens

\begin{tabular}{l|c|c|c|c|c}
\hline Days & \multicolumn{1}{c|}{$\begin{array}{c}\text { Group I } \\
(23 \mathrm{~L}: 1 \mathrm{D})\end{array}$} & $\begin{array}{c}\text { Group II } \\
(4 \mathrm{x}(4 \mathrm{~L}: 2 \mathrm{D}))\end{array}$ & $\begin{array}{c}\text { Group III } \\
(2 \mathrm{x}(8 \mathrm{~L}: 4 \mathrm{D}))\end{array}$ & $\begin{array}{c}\text { Group IV } \\
(16 \mathrm{~L}: 8 \mathrm{D})\end{array}$ & $\mathrm{P}$ \\
\hline & \multicolumn{7}{c}{ Water consumption (mL/chicken/day) } \\
$7-14$ & $116.31 \pm 1.71 \mathrm{a}$ & $113.23 \pm 1.22 \mathrm{ab}$ & $111.60 \pm 3.44 \mathrm{ab}$ & $104.32 \pm 2.36 \mathrm{~b}$ & $*$ \\
$15-21$ & $188.83 \pm 2.96 \mathrm{a}$ & $159.41 \pm 10.93 \mathrm{ab}$ & $179.98 \pm 3.33 \mathrm{ab}$ & $165.22 \pm 4.05 \mathrm{~b}$ & $*$ \\
$22-28$ & $271.87 \pm 8.08 \mathrm{a}$ & $265.02 \pm 3.94 \mathrm{a}$ & $231.61 \pm 6.61 \mathrm{~b}$ & $230.44 \pm 2.15 \mathrm{~b}$ & $* * *$ \\
$29-35$ & $318.30 \pm 8.75$ & $298.84 \pm 3.72$ & $334.45 \pm 13.73$ & $312.19 \pm 6.29$ & $\mathrm{NS}$ \\
$36-42$ & $361.95 \pm 12.76$ & $378.26 \pm 16.42$ & $363.95 \pm 22.21$ & $373.39 \pm 5.52$ & $\mathrm{NS}$ \\
$7-42$ & $251.45 \pm 4.84 \mathrm{a}$ & $242.95 \pm 5.22 \mathrm{ab}$ & $244.32 \pm 4.18 \mathrm{ab}$ & $237.11 \pm 1.62 \mathrm{~b}$ & $*$ \\
\hline
\end{tabular}

Data are given as mean \pm standard error. NS: Non-significant, $* \mathrm{P}<0.05, * * * \mathrm{P}<0.001, \mathrm{a}, \mathrm{b}-$ the difference among the means expressed in different letters in the same line is significant.

Table 5. The effect of different light/dark cycles on carcass characteristics in broiler chickens

\begin{tabular}{l|c|c|c|c}
\hline \multicolumn{1}{c|}{ Proportional values (\%) } & $\begin{array}{c}\text { Group I } \\
(23 \mathrm{~L}: 1 \mathrm{D})\end{array}$ & $\begin{array}{c}\text { Group II } \\
(4 \mathrm{x}(4 \mathrm{~L}: 2 \mathrm{D}))\end{array}$ & $\begin{array}{c}\text { Group III } \\
(2 \mathrm{x}(8 \mathrm{~L}: 4 \mathrm{D}))\end{array}$ & $\begin{array}{c}\text { Group IV } \\
(16 \mathrm{~L}: 8 \mathrm{D})\end{array}$ \\
\hline Carcass yield & $77.40 \pm 1.84$ & $79.51 \pm 0.56$ & $77.63 \pm 1.23$ & $79.09 \pm 0.46$ \\
Thigh & $39.44 \pm 0.52$ & $40.19 \pm 0.49$ & $39.64 \pm 0.41$ & $39.25 \pm 0.46$ \\
Breast & $39.33 \pm 0.39 \mathrm{a}$ & $37.11 \pm 0.62 \mathrm{~b}$ & $36.41 \pm 0.45 \mathrm{~b}$ & $36.98 \pm 0.25 \mathrm{~b}$ \\
Wing & $9.23 \pm 0.33 \mathrm{c}$ & $10.01 \pm 0.21 \mathrm{bc}$ & $10.99 \pm 0.15 \mathrm{a}$ & $10.55 \pm 0.24 \mathrm{ab}$ \\
Back and neck & $11.99 \pm 0.57$ & $12.67 \pm 0.20$ & $12.93 \pm 0.25$ & $13.20 \pm 0.26$ \\
Liver & $2.05 \pm 0.07$ & $2.24 \pm 0.11$ & $2.20 \pm 0.08$ & $2.12 \pm 0.09$ \\
Heart & $0.51 \pm 0.03$ & $0.51 \pm 0.02$ & $0.52 \pm 0.01$ & $\mathrm{NS}$ \\
Spleen & $0.13 \pm 0.01$ & $0.14 \pm 0.01$ & $0.13 \pm 0.01$ & $\mathrm{NS}$ \\
\hline
\end{tabular}

Data are given as mean \pm standard error. NS: Non-significant, $* * * \mathrm{P}<0.001, \mathrm{a}, \mathrm{b}, \mathrm{c}-$ the difference among the means expressed in different letters in the same line is significant.

Table 6. The effect of different light/dark cycles on some blood parameters in broiler chickens

\begin{tabular}{l|c|c|c|c}
\hline \multicolumn{1}{c|}{ Parameters } & $\begin{array}{c}\text { Group I } \\
(23 \mathrm{~L}: 1 \mathrm{D})\end{array}$ & $\begin{array}{c}\text { Group II } \\
(4 \times(4 \mathrm{~L}: 2 \mathrm{D}))\end{array}$ & $\begin{array}{c}\text { Group III } \\
(2 \times(8 \mathrm{~L}: 4 \mathrm{D}))\end{array}$ & $\begin{array}{c}\text { Group IV } \\
(16 \mathrm{~L}: 8 \mathrm{D})\end{array}$ \\
\hline Free $\mathrm{T}_{3}(\mathrm{ng} / \mathrm{dL})$ & $0.78 \pm 0.09$ & $0.79 \pm 0.10$ & $0.69 \pm 0.09$ & $0.60 \pm 0.12$ \\
Free $_{4}(\mathrm{pg} / \mathrm{mL})$ & $2.52 \pm 0.31 \mathrm{~b}$ & $2.88 \pm 0.41 \mathrm{~b}$ & $3.89 \pm 0.48 \mathrm{a}$ & $3.85 \pm 0.27 \mathrm{a}$ \\
Testosterone $(\mathrm{ng} / \mathrm{dL})$ & $31.88 \pm 3.60 \mathrm{a}$ & $28.58 \pm 4.65 \mathrm{ab}$ & $33.83 \pm 4.99 \mathrm{a}$ & $25.67 \pm 1.67 \mathrm{~b}$ \\
Glucose $(\mathrm{mg} / \mathrm{dL})$ & $225.70 \pm 4.61 \mathrm{ab}$ & $204.20 \pm 7.69 \mathrm{~b}$ & $214.20 \pm 5.04 \mathrm{~b}$ & $243.40 \pm 10.30 \mathrm{a}$ \\
Uric acid $(\mathrm{mg} / \mathrm{dL})$ & $4.71 \pm 1.77 \mathrm{~b}$ & $8.31 \pm 0.96 \mathrm{a}$ & $7.8 \pm 1.17 \mathrm{a}$ & $7.27 \pm 0.8 \mathrm{a}$ \\
\hline
\end{tabular}

Data are given as mean \pm standard error. NS: Non-significant, ${ }^{*} \mathrm{P}<0.05$, a, $\mathrm{b}$ - the difference among the means expressed in different letters in the same line is significant.

Table 7. The effect of different light/dark cycles on some welfare parameters in broiler chickens

\begin{tabular}{l|c|c|c|c}
\hline \multicolumn{1}{c}{ Parameters } & $\begin{array}{c}\text { Group I } \\
(23 \mathrm{~L}: 1 \mathrm{D})\end{array}$ & $\begin{array}{c}\text { Group II } \\
(4 \times(4 \mathrm{~L}: 2 \mathrm{D}))\end{array}$ & $\begin{array}{c}\text { Group III } \\
(2 \times(8 \mathrm{~L}: 4 \mathrm{D}))\end{array}$ & $\begin{array}{c}\text { Group IV } \\
(16 \mathrm{~L}: 8 \mathrm{D})\end{array}$ \\
\hline Body temperature $\left({ }^{\circ} \mathrm{C}\right)$ & $42.10 \pm 0.08$ & $42.05 \pm 0.08$ & $42.21 \pm 0.06$ & $42.26 \pm 0.07$ \\
Tibia crude ash level $(\%)$ & $17.78 \pm 0.74$ & $17.99 \pm 0.40$ & $17.23 \pm 0.53$ & $18.14 \pm 0.44$ \\
Ammonia burns (\%) & & & & $2.26 \pm 0.13 \mathrm{a}$ \\
Right foot & $1.5 \pm 0.15 \mathrm{~b}$ & $2.06 \pm 0.12 \mathrm{a}$ & $2.06 \pm 0.12 \mathrm{a}$ & $2.14 \pm 0.06 \mathrm{a}$ \\
Right knee & $1.36 \pm 0.16 \mathrm{~b}$ & $2.06 \pm 0.1 \mathrm{a}$ & $2.16 \pm 0.11 \mathrm{a}$ & $2.2 \pm 0.11 \mathrm{a}$ \\
Left foot & $1.52 \pm 0.12 \mathrm{~b}$ & $2.2 \pm 0.12 \mathrm{a}$ & $2.2 \pm 12 \mathrm{a}$ & $2.06 \pm 0.07 \mathrm{a}$ \\
Left knee & $1.28 \pm 0.16 \mathrm{~b}$ & $2.04 \pm 0.08 \mathrm{a}$ & $1.9 \pm 0.1 \mathrm{a}$ & $* * *$ \\
\hline
\end{tabular}

Data are given as mean \pm standard error. NS: Non-significant, $* * \mathrm{P}<0.01, * * * \mathrm{P}<0.001, \mathrm{a}, \mathrm{b}-$ the difference among the means expressed in different letters in the same line is significant. 


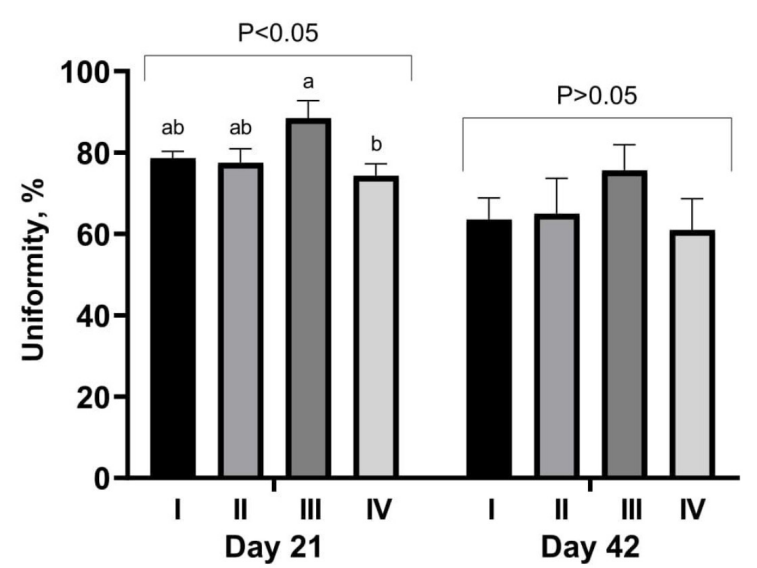

Figure 1. The effect of different light/dark cycles on flock uniformities on days 21 and 42 in broiler chickens

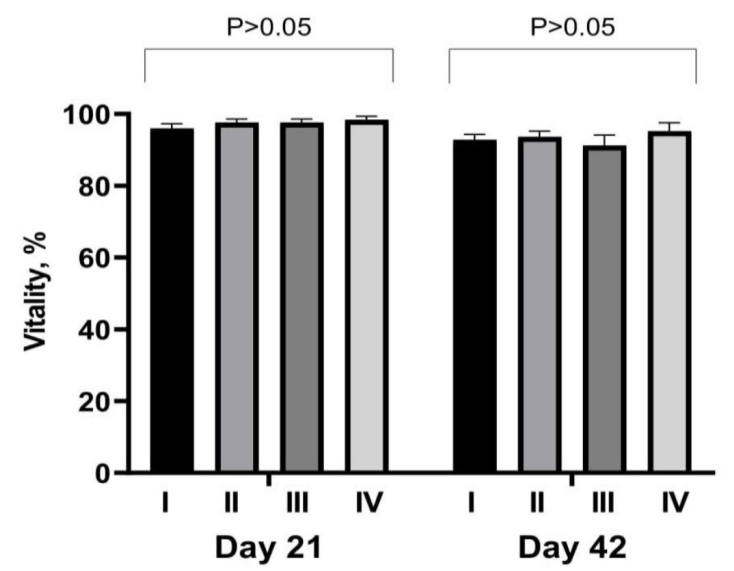

Figure 2. The effect of different light/dark cycles on vitality rate on days 21 and 42 in broiler chickens

\section{Discussion}

The effects of lighting on broiler chickens' performance is a popular area of interest among scientists and the related studies have aimed to find out what lighting model(s) would best improve the performance and welfare of broilers (Olanrewaju et al., 2018). Until recently, 24-hour light or 23-hour light/1-hour dark programmes were implemented in broiler houses because they had positive effects on their performance (Bozkurt, 2017). In recent years, there has been a significant increase in the number of metabolic and skeletal system problems they suffer, followed by consequent mortality rates. This, in turn, stems from the ever-increasing production intensity, which therefore accelerates how fast they grow, largely due to non-intermittent lighting programmes (Abbas et al., 2008; Hassanzadeh et al., 2012; Skrbic et al., 2015; Yang et al., 2015). Therefore, studies on programmes that do not negatively affect the performance of broilers but positively affect their welfare arouse interest. Some stud- ies have investigated different light/dark programmes for different periods in the broiler houses (Abbas et al., 2008; Skrbic et al., 2015). Soliman and Hassan (2020) have found that prolonging light period improves the performance of broilers due to its positive effects on their feeding. However, other studies have reported that implementing darkness for different periods can regulate their metabolic activity and improve their welfare because it provides them the opportunity to rest. Therefore, if darkness is implemented within the physiological limits, it does not negatively affect the broiler chickens' performance; in fact, it can even increase it ( $\mathrm{Li}$ et al., 2010; Hassanzadeh et al., 2012; Calislar et al., 2018). The darkness period set forth by the European Welfare Committee for broilers is at least 6 hours (Bozkurt, 2017). However, the studies (Ozkan et al., 2012; Laçin et al., 2016) have focused on implementing an 8-hour dark programme on broiler chickens, as is already done with other poultry. Non-intermittent darkness period or intermittent (rhythmic or non-rhythmic) programmes can significantly affect several welfare parameters of broilers such as resting, their rush to feed and water and carcass problems caused by the length of the dark period. Studies on the most appropriate length of darkness period have attracted the attention of both scientists and broiler breeders. In this study, the mean live weight at slaughter age (day 42) in group IV - in which a nonintermittent dark programme was implemented - was significantly lower than the other groups. Although there were differences between the mean live weight values in the other groups, these differences were not statistically significant. Similar to the present study, Olanrewaju et al. (2019) found that the short/non-intermittent photoperiod [8L:16D] yielded the lowest growth performance and carcass characteristics in comparison to values of the regular/intermittent photoperiods [2L:2D].

Water consumption was significantly lower in the group in which an 8-hour non-intermittent dark programme was implemented, compared to the other groups. Baykalır and Simsek (2018) found that the serum albumin levels of the broilers were significantly high in broiler houses where they implemented an 8-hour nonintermittent dark programme. These results indicated that the prolonged darkness period caused the broilers to feel thirsty, thereby affecting their metabolism. Soliman and Hassan (2020) reported that intermittent lighting on a 16L:8D regimen (4L:2D, 4 times) caused broiler chickens to drink less water compared to those exposed to the continuous lighting using 23L:1D and $18 \mathrm{~L}: 6 \mathrm{D}$ regimens.

The groups' flock uniformity on days 21 and 42 was calculated in the study. Groups III and IV had the highest and lowest values, respectively. The difference between their mean values on day 21 was significant. Although similar findings were obtained on day 42 , there was no statistical difference between the mean values. Particularly low uniformity in group IV was associated with the fact that the lighting programme implemented on this group caused some of the broilers in the flock to either 
weaken or grow stronger. The stronger ones gained more live weight by consuming more feed, whilst the weaker ones fell behind more frequently. This impaired the uniformity of the flock. The increase of uniformity in the $2 x$ (8L:4D) group indicated that this programme motivated all of the broilers in a similar way when it came to feed consumption.

Vitality values were similar across all groups. Likewise, Ilhan and Yetisir (2009) found that non-intermittent and intermittent lighting programmes did not affect mortality rates. On the other hand, Abbas et al. (2008) found that mortality rate of the broilers they studied dropped significantly upon being placed in an intermittent lighting programme (2L:2D). Hassanzadeh et al. (2012) discovered broilers that died from ascites decreased significantly when they were exposed to a $1 \mathrm{~L}: 3 \mathrm{D}$ programme between days 3-14 and 10-21 compared to those in the non-intermittent lighting programme (23L:1D).

Carcass characteristics of the broilers revealed that group I had a high breast rate and groups III and IV had a high wing rate. This situation was associated with the fact that the breast grew fat faster depending on the live weight but the weight gain was slower in the wing with a higher bone rate (Abdullah and Matarneh, 2010). Li et al. (2010) implemented four lighting programmes (23L:1D, 20L:4D, 16L:8D, and 12L:12D) on broiler chickens. They found that as the light period was prolonged, the pectoral muscle rate increased and the carcass yield and leg and wing rates were similar among the groups. Ilhan and Yetisir (2009) implemented several light/dark cycles at different periods in the broiler houses. They found that the groups were similar in terms of carcass yield and weight and rate of abdominal fat increased in groups subjected to an early period intermittent ( 8 hours on days $4-10$ ) lighting programme. However, they also discovered that the group in non-intermittent lighting programme exhibited a significant drop in wing weight and rate.

Free $T_{3}$ and $T_{4}$ are important anabolic hormones, as they play an important role in the protein, carbon-hydrate, and lipid metabolisms. Abbas et al. (2008) reported that both non-intermittent and intermittent lighting programmes increased the serum $\mathrm{T}_{3}$ level significantly when compared to non-intermittent lighting programmes. Additionally, serum melatonin levels increased as the dark period was prolonged. This in turn elevated the $\mathrm{T}_{4}$ levels by increasing the leptin level (Charles et al., 1992; Legradi et al., 1997). Similarly, in this study, free $T_{4}$ level increased significantly in group IV and in group III. On the contrary, Hassanzadeh et al. (2012) observed that the darkness period significantly lowered broilers' serum $\mathrm{T}_{3}$ and $\mathrm{T}_{4}$ levels in contrast to those that were involved in a non-intermittent lighting programme. The decrease in these hormones reduced their metabolic load and the need of the body for oxygen. This in turn increases their resistance against ascites and other cardio-vascular diseases. In a separate study, Hassanzadeh et al. (2005) reported that intermittent lighting programmes lowered especially young broiler chickens' plasma $\mathrm{T}_{3}$ levels. They also increased their $\mathrm{T}_{4}$ levels, thus leading to decreased metabolic load. Serum testosterone hormone levels dropped significantly especially in the group exposed to $16 \mathrm{~L}: 8 \mathrm{D}$. Testosterone hormone provides formation of more muscles in males; therefore, one could associate the low testosterone level in broilers in this lighting group with having a low live weight. Similarly, Charles et al. (1992) found that the long light period caused an increased testicle weight as well as an elevation in plasma androgen levels in the male broilers, especially those that were young. In contrast, Kühn et al. (1996) implemented 23L:1D and 1L:3D in broiler houses and determined that their plasma testosterone levels of the male broilers exposed to intermittent lighting were significantly high. The highest serum glucose levels were observed in group exposed to non-intermittent restricted lighting. This was followed by those exposed to non-intermittent lighting and intermittent lighting programmes. The blood glucose level is an important indicator of stress. Corticosterone secreted under stress relies on stored glycogen to quickly provide the body energy, in turn raising blood glucose levels through gluconeogenesis (Ozhan et al., 2016). The fluctuations in serum glucose levels in the groups in this study could be associated with stress. The high glucose level in group IV may be related to high stress.

Serum uric acid level is also an important indicator of stress. Particularly uric acid, which is a product of protein metabolism, forms when the body tries to obtain gluconeogenesis-related energy if it cannot get enough carbon-hydrate driven energy (Ozhan et al., 2016). The fact that uric acid levels were higher in the intermittent lighting programmes than the non-intermittent lighting programme implies that the broilers in these groups obtained more energy via gluconeogenesis.

Light has an important effect on broilers' body temperatures in the broiler houses (Pandey, 2019). In this study, it was considered that the increasing feed consumption would increase body temperature depending on the length of the light period. However, the findings suggested that there was no significant difference among the groups in terms of body temperature, since their feed consumption rates were similar.

Increasing feed consumption and physical activity also have important effects on bone quality (Pandey, 2019). No significant difference between the tibia ash values of the groups with similar feed consumption as well as the length of the light period, and the difference between the light-dark periods did not affect their bone ash levels.

Broilers in groups exposed to restricted lighting had high ammonia burns. This could be associated with the fact that the broilers in this group moved less. Skrbic et al. (2015) had exposed broilers to $16 \mathrm{~L}: 4 \mathrm{D}: 2 \mathrm{~L}: 2 \mathrm{D}$ between days 8-39, 23L:1D between days 40-42 (Group 1), 16L:8D between days $8-14,16 \mathrm{C}: 3 \mathrm{~K}: 2 \mathrm{~L}: 3 \mathrm{D}$ between days 15-21, 16L:2D:4L:2D between days 22-28, 16L:1D:6L:1D between days 29-35, and 23L:1D be- 
tween days 36-42 (Group 2). They found that group 1 had significantly high footpad problems, whereas group 2 had more inflammation of the knee joint.

In conclusion, it appears that the non-intermittent lighting programme (8-hour non-intermittent dark period) significantly worsened both broilers' performance and welfare. In the intermittent lighting programmes, it is important to determine the appropriate period, in which broilers would not be dehydrated. Intermittent lighting programmes can be implemented to save energy. They moreover allow broilers to rest more. This study yielded similar findings in both intermittently restricted lighting programmes in terms of the examined parameters. Broiler houses can be illuminated with different intermittently restricted lighting programmes.

\section{Acknowledgments}

This study was funded by the Frrat University Scientific Research Projects Unit (V.F. 17.17).

\section{References}

Abbas A.O., Alm El-Dein A.K., Desoky A.A., Galal M.A.A. (2008). The effects of photoperiod programs on broiler chicken performance and immune response. Int. J. Poultry Sci., 7: 665-671.

Abdullah A.Y., Matarneh S.K. (2010). Broiler performance and the effects of carcass weight, broiler sex, and postchill carcass aging duration on breast fillet quality characteristics. J. Appl. Poultry Res., 19: 46-58.

Baykalır Y., Simsek Ü.G. (2018). Effect of different photoperiod treatments on serum albumin levels in broiler. Proc. I Zeugma International Congress of Multidisciplinary Studies, Gaziantep, Turkey, 13-16.09.2018, p. 88-91.

Baykalir Y., Simsek U.G., Erisir M., Otlu O., Gungoren G., Gungoren A., Aslan S. (2020). Photoperiod effects on carcass traits, meat quality, and stress response in heart and lung of broilers. S. Afr. J. Anim. Sci., 50: 138-149.

Bozkurt Z. (2017). Legal requirements for the welfare standards of broiler and layer hens in the European Union and Turkey's compliance. J. Bahri Dagdas Anim. Res., 6: 23-35.

Calislar S., Yeter B., Sahin A. (2018). Importance of melatonin on poultry. J. Agric. Nat., 21: 987-997.

Charles R.G., Robinson F.E., Hardin R.T., Yu M.W. (1992). Growth, body composition, and plasma androgen concentrations of male broiler chickens subjected to different regimes of photoperiod and light intensity. Poultry Sci., 71: 1595-1605.

Hassanzadeh M., Shojadoost B., Feyzih A., Buyse J., Decuypere E. (2005). Effect of intermittent lighting schedules at the young age of broiler chickens on the incidence of ascites and metabolic parameters. Arch. Geflugelkd., 69: 57-61.

Hassanzadeh M., Al-Masri F., Maddadi, M.S., Shojaei H., Eghbalian A., Abbasi S., Yousefi K. (2012). Comparative study on the beneficial effects of different dark length schedules on the incidence of ascites and metabolic parameters in fast growing broiler chickens. Iran J. Vet. Med., 6: 113-121.

Ilhan U., Yetisir R. (2009). Comparison of lighting programs widely used in broiler production with respect to performance and some carcass properties. Selcuk J. Agr. Food Sci., 23: 63-72.

Jia Y., Yang M., Zhu K., Wang L., Song Y., Wang J., Qin W., Xu Z., Chen Y., Liua G. (2016). Melatonin implantation improved the egg-laying rate and quality in hens past their peak egg-laying age. Sci. Rep., 6: 39799.

Kühn E.R., Darras V.M., Gysemans C., Decuypere E., Berghman L.R., Buyse J. (1996). The use of intermittent lighting in broiler raising: 2. Effects on the somatotrophic and thyroid axes and on plasma testosterone levels. Poultry Sci., 75: 595-600.

Laçin E., Çoban Ö., Sabuncuoğlu N. (2016). Effect of continuous and constant lighting regimes on organ growth in broilers. Atatürk Üniversitesi Vet. Bil. Derg., 11: 60-66.

Legradi G., Emerson C.H., Ahima R.S., Flier J.S., Lechan R.M. (1997). Leptin prevents fasting-induced suppression of prothyrotropin-releasing hormone messenger ribonucleic acid in neurons of the hypothalamic paraventricular nucleus. Endocrinology, 138: 2569-2576.

Li W., Guo Y., Chen J., Wang R., He Y., Su D. (2010). Influence of lighting schedule and nutrient density in broiler chickens: Effect on growth performance, carcass traits and meat quality. AsianAust. J. Anim. Sci., 23: 1510-1518.

Manfio E.S., Duarte Jácome I.M.T., Serpa F.C,. Zanchin L.F., Burbarelli M.F.C., Przybulinski B.B., Barbosa D.K., Garciab R.G. (2019). Intermittent lighting program does not hinder the performance of broiler chickens and promotes energy economy. Can. J. Anim. Sci., 100: 228-233.

Olanrewaju H.A., Miller W.W., Maslin W.R., Collier S.D., Purswell J.L., Branton S.L. (2018). Influence of light sources and photoperiod on growth performance, carcass characteristics, and health indices of broilers grown to heavy weights. Poultry Sci., 97: 1109-1116.

Olanrewaju H.A., Miller W.W., Maslin W.R., Collier S.D., Purswell J.L., Branton S.L. (2019). Interactive effects of light-sources, photoperiod, and strains on growth performance, carcass characteristics, and health indices of broilers grown to heavy weights. Poultry Sci., 98: 6232-6240.

Ozhan N., Simsek U.G., Ozcelik M. (2016). Comparison of floor and cage housing systems in terms of some welfare assessments in broiler. Ankara Üniv. Vet. Fak. Derg., 63: 317-322.

Ozkan S., Yalcın S., Babacanoglu E., Kozanoglu H., Karadas F., Uysal S. (2012). Photoperiodic lighting (16 hours of light: 8 hours of dark) programs during incubation: 1 . Effects on growth and circadian physiological traits of embryos and early stress response of broiler chickens. Poultry Sci., 91: 2912-2921.

Pandey U. (2019). Effect of lighting in broiler production. Acta Sci. Agric., 3: 114-116.

Simsek U.G., Ozhan N. (2015). Effects of flock size in broilers reared in a floor system on performance, some blood parameters, bone quality and musculus pectoralis $\mathrm{pH}$ level. Ann. Anim. Sci., 15: 505-516.

Skrbic Z., Pavlovski Z., Lukic M., Petricevic V. (2015). Incidence of footpad dermatitis and hock burns in broilers as affected by genotype, lighting program and litter type. Ann. Anim. Sci., 15: 433-445.

Soliman E.S., Hassan R.A. (2019). Impact of lighting color and duration on productive performance and Newcastle disease vaccination efficiency in broiler chickens. Vet. World., 12: 1052-1059.

Soliman F.N., El-Sabrout K. (2020). Light wavelengths/colors: Future prospects for broiler behavior and production. J. Vet. Behav., 36: 34-39.

T.S.I. (2014). Turkish Standards Institute "Chicken body meat-shredding, packaging, transportation and preservation rules" TS 5890.

Yang H., Xing H., Wang Z., Xia J., Wan Y., Hou B., Zhang J. (2015). Effects of intermittent lighting on broiler growth performance, slaughter performance, serum biochemical parameters and tibia parameters. Ital. J. Anim. Sci., 14: 684-689.

Received: 14 IX 2020

Accepted: 5 X 2021 